The Common Agricultural Policy of the European Union the present and the future

EU Member States

point of view 



\section{INSTITUTE OF AGRICULTURAL AND FOOD ECONOMICS NATIONAL RESEARCH INSTITUTE}

\section{The Common Agricultural Policy of the European Union - the present and the future}

\section{EU Member States point of view}

Editors:

dr Marek Wigier

prof. dr hab. Andrzej Kowalski

Proceedings of the International Scientific Conference

"The Common Agricultural Policy of the European Union - the present and the future" Multi-Annual Programme 2015-2019

"The Polish and the EU agricultures 2020+. Challenges, chances, threats, proposals" 5-7 December 2017 Stare Jabłonki, Poland

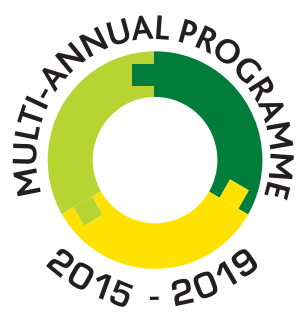

THE POLISH AND THE EU AGRICULTURES 2020+ CHALLENGES, CHANCES, THREATS, PROPOSALS

Warsaw 2018 
This monograph was prepared under the Multi-Annual Programme 2015-2019

"The Polish and the EU agricultures 2020+. Challenges, chances, threats, proposals".

The publication is a collection of selected papers delivered at the 22th edition of the International Scientific Conference organized by the Institute of Agricultural and Food Economics - National Research Institute. The theme of the conference was "The Common Agricultural Policy of the European Union the present and the future. The conference was placed on 5-7 December 2017 in Stary Jabłonki in Poland. Common Agricultural Policy was and still is one of the key pillars of European integration. Published in two volumes materials refer directly to the current and future of the CAP in EU and non EU member states, the strategic objectives and principles of agricultural policy for the agri-food sector and rural areas, address the issues of equilibrium between agriculture, forestry and land use, relate to the dilemmas for the EU budget and the CAP after 2020, CAP instruments and their adjustment, transformations of the rural economy and programming of the rural and agricultural policy, as well as productivity and production efficiency and tensions between sectoral action and between different models of territorial activities.

In the Scientific Committee of the Conference was participated: Prof. Andrzej Kowalski (IAFE-NRI, Poland), Prof. Drago Cvijanonivić (University of Kragujevac, Serbia), Prof. Thomas Doucha (IAEI, Czech Republic), Noureddin Driouech, PhD (CIHEAM, Italy), Prof. Szczepan Figiel (IAFE-NRI, Poland), Prof. Masahiko Gemma (Waseda University, Japan), Prof. Wojciech Józwiak (IAFE-NRI, Poland), Prof. Jacek Kulawik (IAFE-NRI, Poland), Prof. Yuriy Oleksiyovych Lupenko (IAE, Ukraina), Prof. Věra Majerová (CULS, Prague), Prof. Dimitre Nikolov (IAE, Bulgaria), Maire Nurmet, PhD (EMÜ, Estonia), Prof. Gabriel Popescu (ASE, Romania), Norbert Potori, PhD (AKI, Hungary), Prof. Włodzimierz Rembisz (IAFE-NRI, Poland), Piotr Szajner, PhD (IAFE-NRI, Poland), Prof. Alina Sikorska (IAFE-NRI, Poland), Prof. Jonel Subić (IAE, Serbia), Prof. Samuele Trestini (UNIPD, Italy), Prof. Olga Varchenko (Bila Tserkva National Agrarian University, Ukraine), Dipl.-Ing. Klaus Wagner (AWI, Austria), Marek Wigier, PhD (IAFE-NRI, Poland), Prof. Józef St. Zegar (IAFE-NRI, Poland)

In the Organising Committee of the Conference was participated: Małgorzata Bułkowska (IAFE-NRI, Poland), Anna Hankiewicz (IAFE-NRI, Poland), Joanna Jaroszewska (IAFE-NRI, Poland), Joanna Korczak (IAFE-NRI, Poland), Krzysztof Kossakowski (IAFE-NRI, Poland), Irena Mikiewicz (IAFE-NRI, Poland), Małgorzata Mikołajczyk (IAFE-NRI, Poland), Lech Parzuchowski (IAFE-NRI, Poland), Ewa Sierakowska (IAFE-NRI, Poland), Paulina Smakosz (IAFE-NRI, Poland), Leszek Ślipski (IAFE-NRI, Poland), Marek Wigier, PhD (IAFE-NRI, Poland).

Reviewers:

Professor Dimitre Nikolov, Institute of Agricultural Economics, Sofia, Bulgaria

Professor Gabriel Popescu, The Bucharest University of Economic Studies, Bucharest, Romania

Professor Samuele Trestini, University of Padva, Italy

Proofreader

Katarzyna Mikulska

Technical editors:

Joanna Jaroszewska, Barbara Pawtowska, Ewa Sierakowska, Kamila Tomaszewska,

Barbara Walkiewicz

Translated by

Summa Linguae S.A.

Cover Project

Leszek Ślipski

ISBN 978-83-7658-743-1

DOI: $10.30858 / \mathrm{pw} / 9788376587431$

Instytut Ekonomiki Rolnictwa i Gospodarki Żywnościowej

- Państwowy Instytut Badawczy

ul. Świętokrzyska 20, 00-002 Warszawa

tel.: (22) 5054444

faks: (22) 5054636

e-mail:dw@ierigz.waw.pl

http://www.ierigz.waw.pl 


\section{Contents}

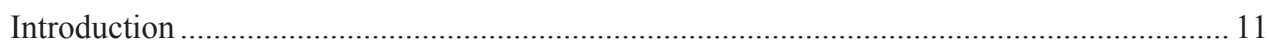

Dr Marek Wigier

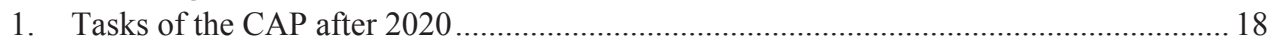

Dr hab. Julian Krzyżanowski

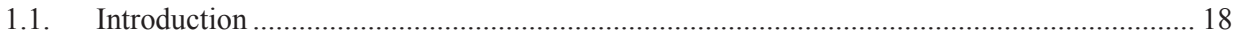

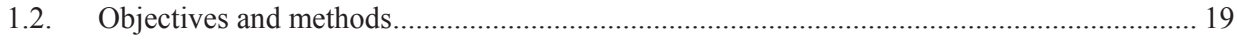

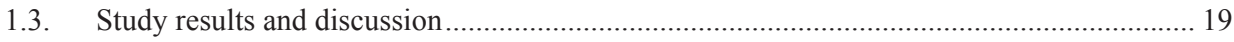

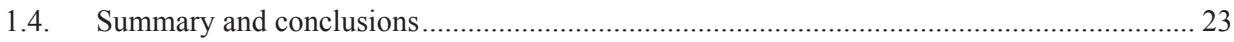

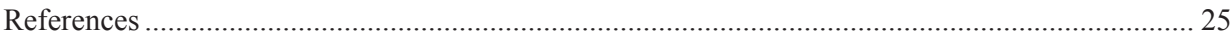

2. An assessment of the regional impacts of post-2020 CAP budgetary cuts on production

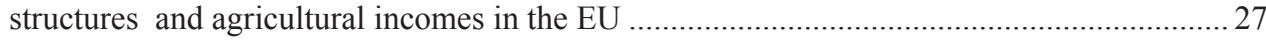

PhD Norbert Potori, PhD János Sávoly, PhD Szabolcs Biró

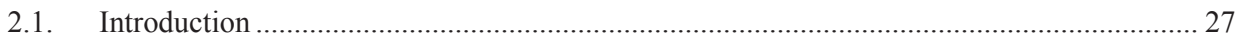

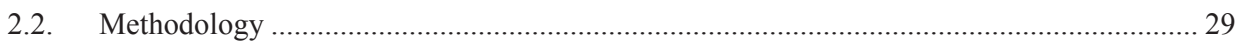

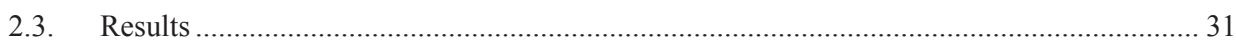

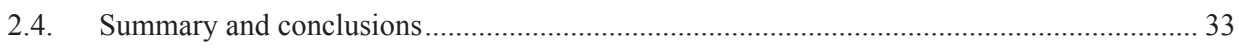

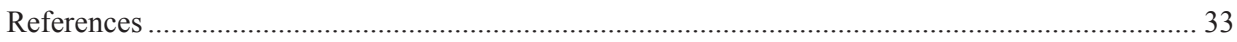

3. Is there room for financial instruments in the Common Agricultural Policy? Casus of

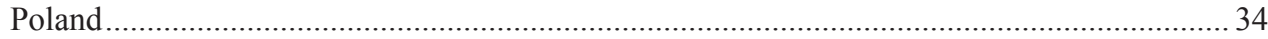

Prof. dr hab. Jacek Kulawik, PhD Barbara Wieliczko, PhD Michat Soliwoda

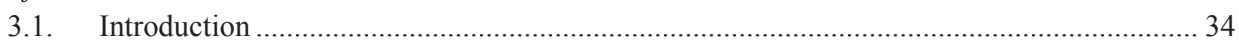

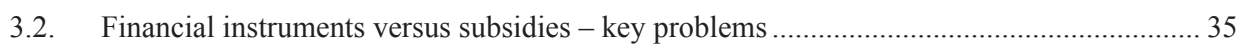

3.3. The use of financial instruments under the EU policy ......................................................... 37

3.4. Example of the use of FI in the 2014-2020 programming period ......................................... 38

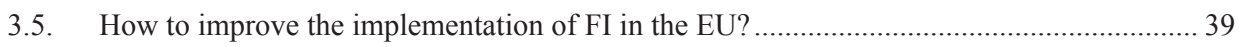

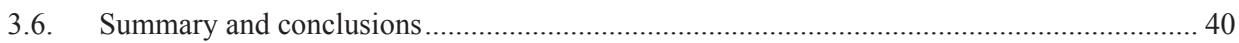

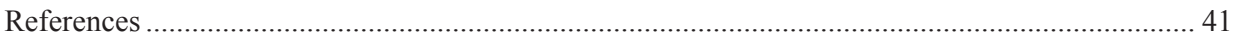

4. The past, present and future of the CAP - the Hungarian viewpoint ............................. 43

Dr Tamás Mizik

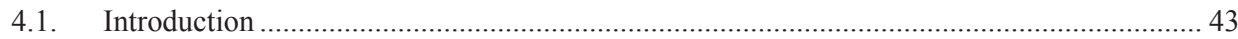

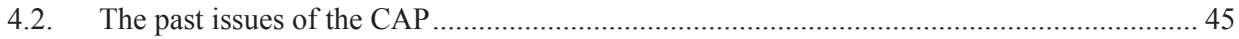

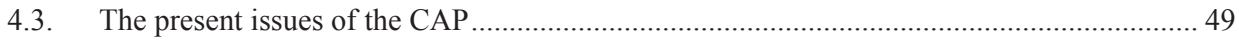

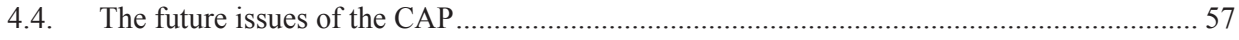

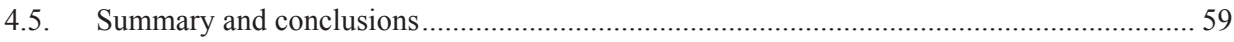

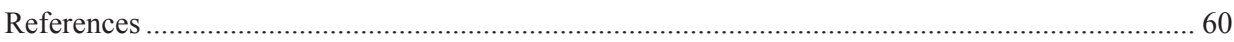


5. Going beyond the Rural Development Programme: a Master Plan for Austria's rural areas in the framework of the CAP

Dip.-Ing. Klaus Wagner

5.1. Introduction

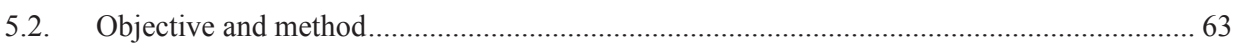

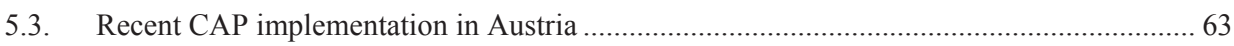

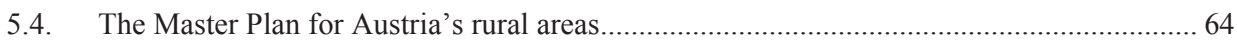

5.5. CAP in the system of the EU policy objectives and in the view of regional science

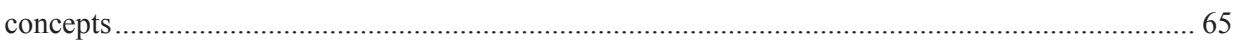

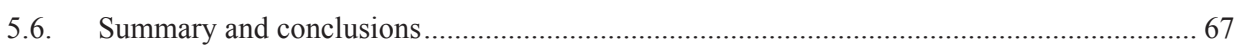

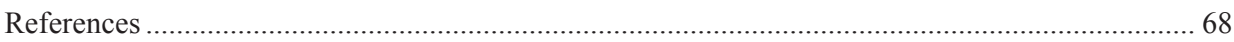

6. Possibilities to connect the Romanian agricultural research to the market requirements 69 Prof. Gabriel Popescu

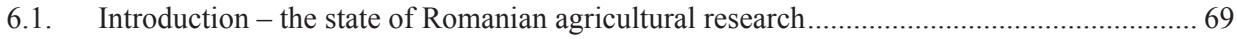

6.2. The problems faced by agricultural research since 1990 ..................................................... 71

6.3. Possible solutions for the recovery of Romanian agricultural research ................................ 76

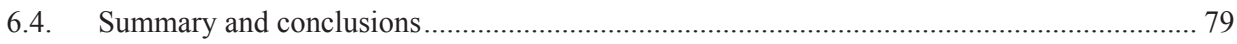

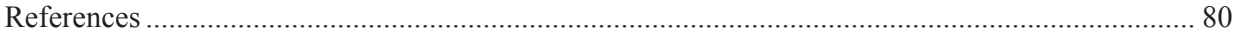

7. Price relationships of the production factors as exogenous determinants of production in agriculture.

Prof. dr hab. Włodzimierz Rembisz, PhD Adam Waszkowski

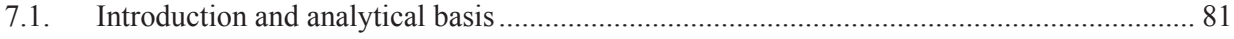

7.2. Relationships of prices of the capital, labour and land factors - hypothetical approach...... 83

7.3. Relationships of prices of the capital, labour and land factors - empirical approach .......... 84

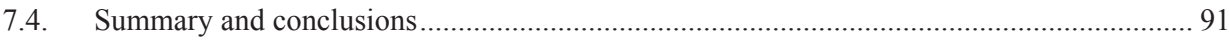

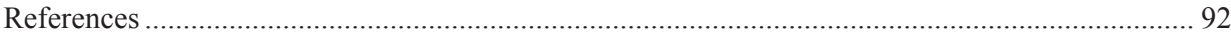

8. Effects of direct payments on agricultural development in Bulgaria ............................. 93 PhD Bozhidar Ivanov

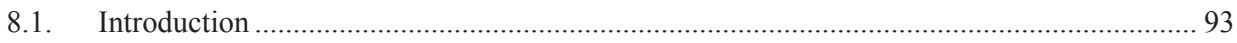

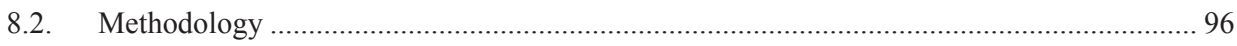

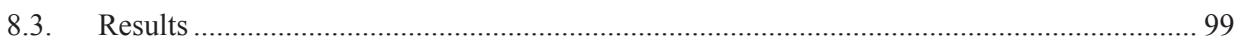

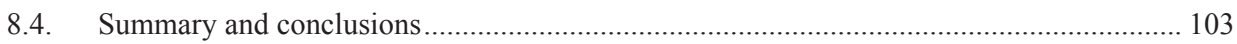

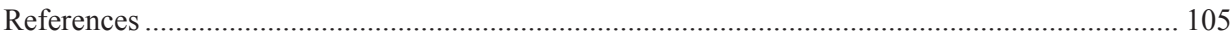

9. Re-adjusting risk management within the CAP: evidences on the implementation of the

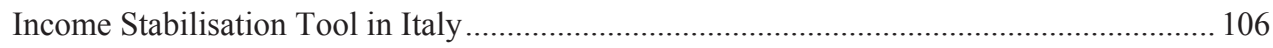
Prof. Samuele Trestini, PhD Elisa Giampietri

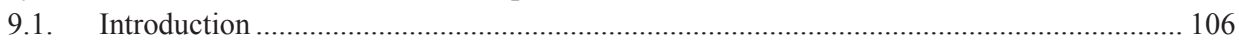

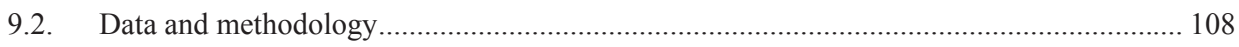




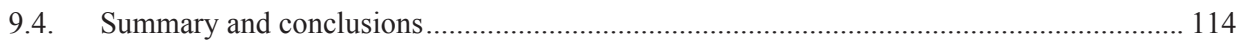

References

10. Comparison of risk management tools under the CAP of the EU, the US Farm Bill

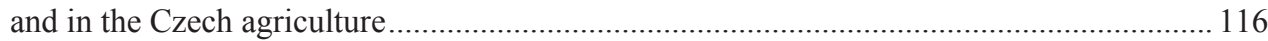
Ing. Václav Vilhelm, CSc., Ing. Sumudu Namali Gouri Boyinová, PhD Jindřich Špička

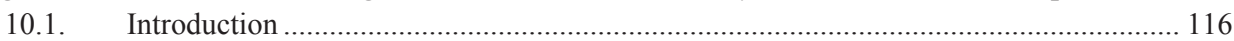

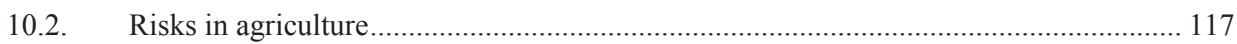

10.3. Risk management policy in the United States Farm Bill 2014 _..................................... 118

10.4. Risk management policy of the European Union's CAP ................................................ 119

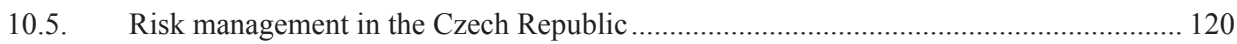

10.6. Comparative analysis of risk management policies ........................................................ 121

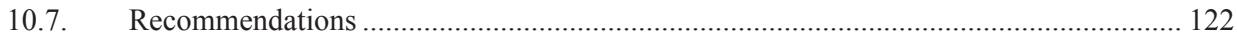

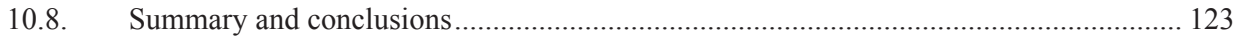

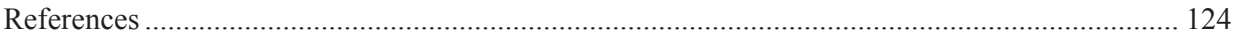

11. Factors determining the crop insurance level in Poland taking into account the level

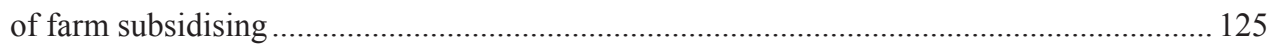

Prof. Adam Was, PhD Pawet Kobus

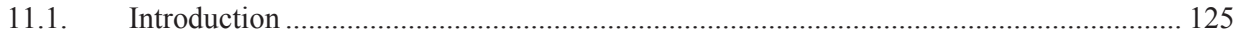

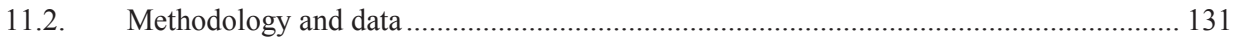

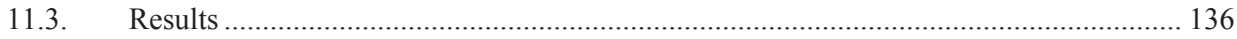

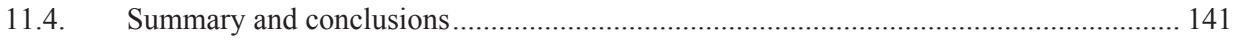

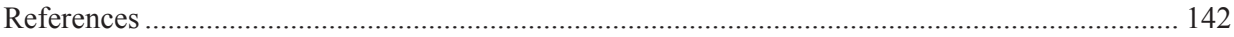

12. Farms and agricultural enterprises for development of sustainable and smart cooperatives: a multifactor approach using digital farm management ............................... 147 Prof. dr habil Adriana Mihnea, Prof. dr Dimitre Nikolov, dr Krasimir Kostenarov

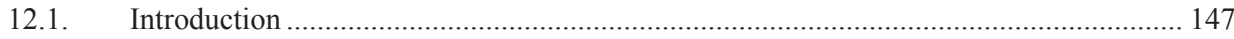

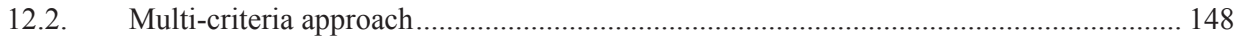

12.3. Construction of Farm Management Model ................................................................ 150

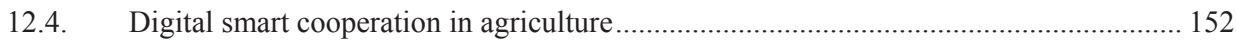

12.5. Application of the ANP Farm Management Model ....................................................... 154

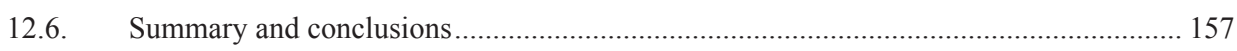

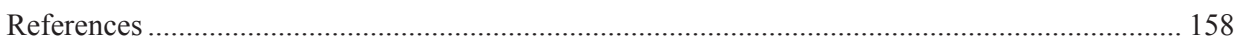

13. Brexit - potential implications for the Polish food sector .............................................. 159

Dr Katarzyna Kosior, Dr Łukasz Ambroziak

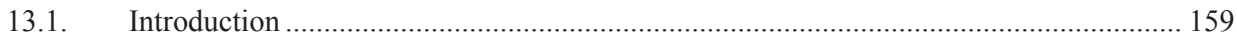

13.2. Negotiations on Brexit - what should be the model of the future relations? ..................... 161

13.3. The future of the EU finances and the CAP in the context of Brexit .............................. 163 
13.4. Impact of possible changes in the CAP budget on the net balance of Poland and transfers to the Polish agriculture.

13.5. The potential impact of Brexit on agri-food trade between Poland and the United

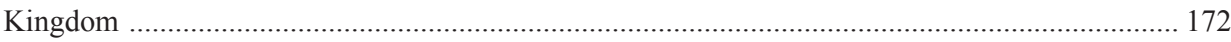

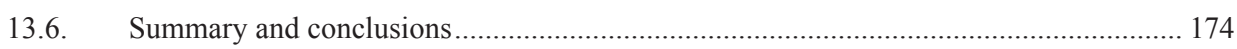

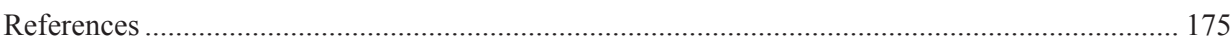

14. The Transatlantic Trade and Investment Partnership (TTIP): a threat or an opportunity for the EU-Mediterranean agriculture and agri-food sector? An exploratory survey ........... 177 Dipl.-Ing. Katja Pietrzyck, PhD Noureddin Driouech, Prof. Brigitte Petersen

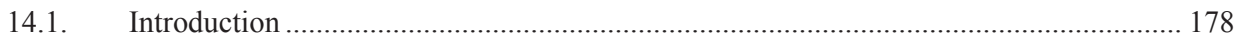

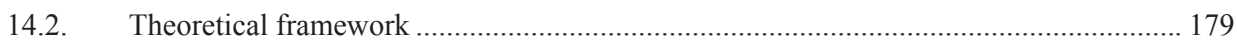

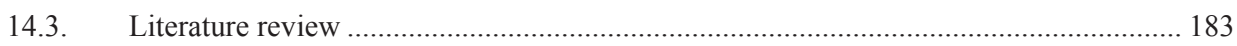

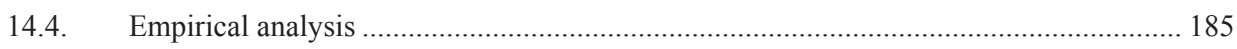

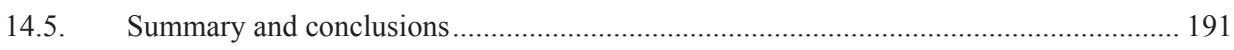

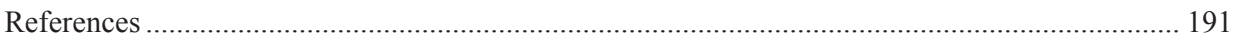

Appendix I: Overview of trade statistics regarding selected products ........................................... 195

15. The concept of short supply chains in the food economy............................................. 196

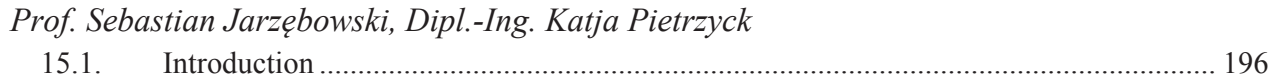

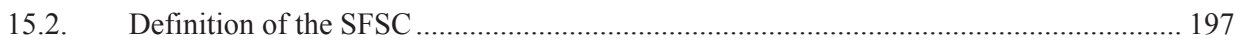

15.3. Development of short supply chains in Europe............................................................. 201

15.4. Global context of European short supply chains ........................................................... 205

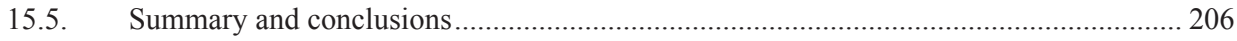

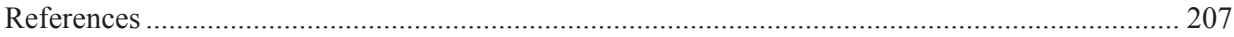

16. The CAP implementation in Wallonia - today performance and questions for the future -

A brief supplementary comment from Warmia and Mazury perspective............................. 209

PhD Philippe Burny, PhD Benon Gazinski

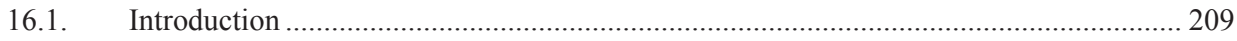

16.2. Implementation of the green payment in Wallonia in 2015 ........................................ 210

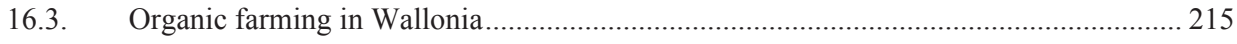

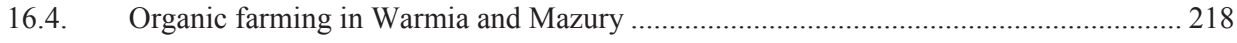

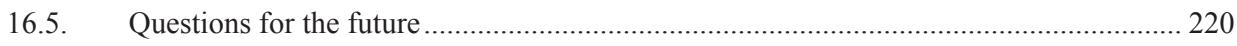

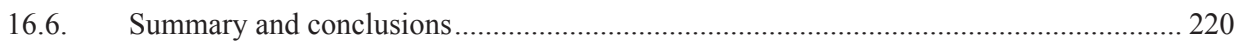

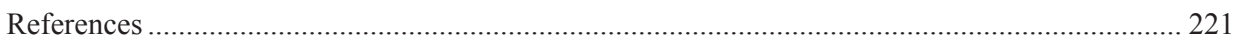

17. Afforestation of agricultural land financed from the RDP 2014-2020 ....................... 224

PhD Marek Zieliński

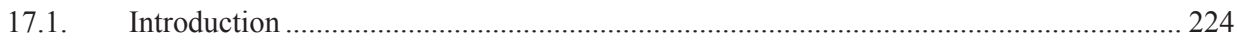

17.2. Natural farming conditions in Poland in regional terms................................................. 225 
17.3. The impact of natural farming conditions in Poland on the economic situation and the possibility of afforestation on farms

17.4. Land afforestation financed from the RDP 2014-2020 in regional terms

17.5. Importance of land afforestations financed under the RDP 2014-2020 in the EU climate policy for 2021-2030.

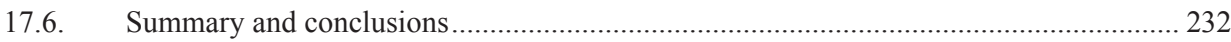

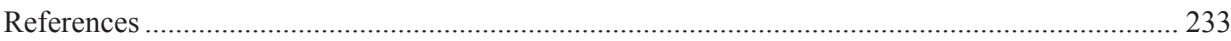

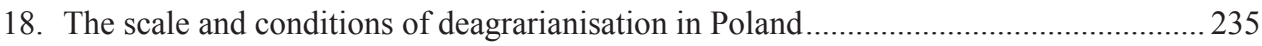

PhD Michat Dudek, PhD Bożena Karwat-Woźniak

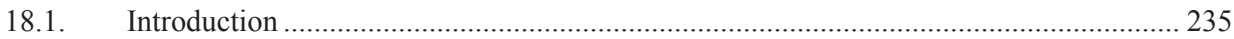

18.2. The conditions of the decrease in employment in agriculture ......................................... 236

18.3. The change in the scale of employment in agriculture in Poland and its conditions....... 238

18.4. The instruments of the Cohesion Policy and agriculture and rural development of the EU

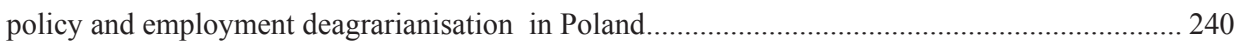

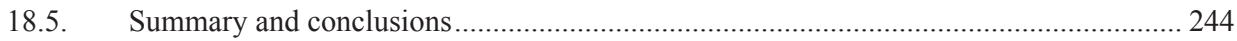

References 245

19. Socio-economic and environmental parameters and results of rural development under the CAP: the case of Bulgaria ................................................................................................ 247 Prof.dr.hab. Julia Doitchinova, Prof.dr.hab. Ivan Kanchev, Ass.Prof. Ralitsa Terziyska PhD, Ass.Prof. Kristina Todorova PhD

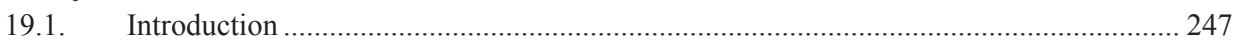

19.2. Changes in Bulgarian rural areas - socio-economic and environmental aspects................ 248

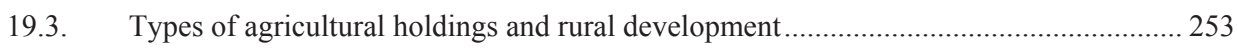

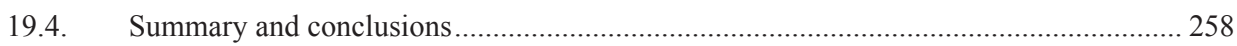

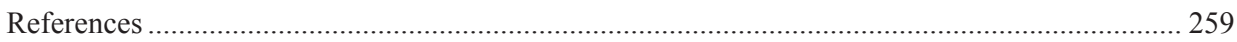

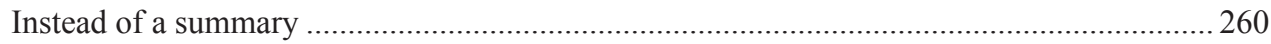

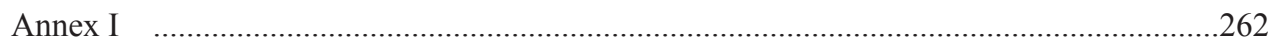




\title{
13. Brexit - potential implications for the Polish food sector
}

\author{
Dr Katarzyna Kosior, Dr Łukasz Ambroziak \\ Institute of Agricultural and Food Economics - National Research Institute, \\ Warsaw, Poland \\ Kosior@ierigz.waw.pl,Ambroziak@ierigz.waw.pl
}

DOI: $10.30858 / \mathrm{pw} / 9788376587431.13$

\begin{abstract}
The chapter discusses the possible consequences of Brexit for the Polish food sector. The focus was on two areas - the budget of the CAP and the agri-food trade of Poland and the United Kingdom. It was found that the Polish food sector may be particularly affected by the implications of Brexit. On the one hand, the growing pressure to limit spending on the CAP and, on the other, a very likely deterioration in terms of mutual trade in agri-food products will be a problem. In the moderate scenario, which provides relatively small reductions in the CAP expenditure, transfers to Polish agriculture could decrease by almost EUR 290 million on average per year. In the radical scenario, reductions could amount to nearly EUR 1 billion on average per year. In the case of restoring customs tariffs resulting from the WTO Most Favoured Nation Clause, one can expect a breakdown in the Polish exports to the UK of the most important agri-food product groups.
\end{abstract}

Keywords: Brexit, CAP budget, agri-food trade

JEL codes: E62, F13, F50, H77, Q17, Q18

\subsection{Introduction}

In the referendum held on 23 June 2016, the British voted for the exit of the United Kingdom from the European Union. On 29 March 2017, after 44 years of membership, the British government notified the European Council of its desire to launch a procedure for the UK to exit the EU in accordance with Article 50 of the Treaty on the European Union. Thus, a two-year period of negotiating the conditions for the exit of the United Kingdom from the EU began. According to the schedule resulting from the Treaty provisions, the United Kingdom will cease to be a member of the EU on 29 March 2019. This will also happen when the agreement setting out the conditions for the exit is not adopted and when the European Council, in consultation with the United Kingdom, does not decide unanimously to extend the negotiations. Although there are voices indicating the possibility of withdrawal of Great Britain from negotiations on the 
exit from the EU, as well as ideas of another referendum on the EU membership, the British government upholds its decision of March 2017, and is gradually preparing the country to withdraw from the European structures.

Brexit will, undoubtedly, be one of the most difficult moments and experiences in the history of the European integration. Due to the high degree of integration of the British economy with the economies of other EU countries, the economic costs of the British-EU divorce may be high. The UK's exit from the EU may significantly affect the shape of the future Common Agricultural Policy, including the framework of functioning of the agri-food sectors of the EU Member States. The UK is now both one of the main net contributors to the EU budget, including the CAP budget, as well as one of the main net importers of agri-food products from the EU countries. Therefore, Brexit will have important budgetary and commercial consequences for both the UK and other EU Member States. The Polish food sector can be particularly affected by the effects of Brexit. Poland is currently the largest net beneficiary of the CAP budget - in 2016, Polish farmers and rural residents received almost EUR 5 billion under direct payments and other support programmes. At the same time, Poland is one of the main exporters of agri-food products to the EU countries. The value of Polish agri-food exports has increased significantly in the recent period, mainly due to unrestricted access to the single European market. The particularly high growth rate concerned agri-food exports from Poland to Great Britain. In 2016, food producers exported products worth over EUR 2 billion to the British market, which accounted for nearly $9 \%$ of the value of Polish agri-food exports. Currently, the United Kingdom is the second, after Germany, recipient of the Polish agri-food products.

The purpose of the chapter is to discuss the possible consequences of Brexit for the Polish food sector. The potential impact of Brexit on the CAP budget and agri-food trade between Poland and the United Kingdom will be the main focus. The distribution structure is as follows. The second section will briefly discuss the main problems of negotiations on the UK's exit from the EU, the positions of both parties and proposals for arranging future relations between London and the EU mentioned in the discussions. Estimates about a possible EU income gap in relation to the UK's exit and the on-going debate on the multiannual financial framework and the CAP after 2020 will be presented in the third section. An analysis of the impact of possible changes in the level of CAP financing on the changes in the net balances of Poland in the CAP area and financial transfers to Polish agriculture will be presented against this background. The fourth section will be devoted to the assessment of the impact of possible changes in trading conditions on agri-food trade between Poland and the United King- 
dom. The assessment in this part refers to the most pessimistic variant, assuming the restoration of customs tariffs in mutual trade, resulting from the Most Favored Nation clause (MFN) adopted in the framework of the World Trade Organization (WTO). The chapter finishes with a summary.

\subsection{Negotiations on Brexit - what should be the model of the future relations?}

Negotiations on the conditions for the United Kingdom to exit the EU began in May 2017. However, talks of the first phase of negotiations did not cover any issues related to the shape of future trade relations between Great Britain and the EU. The first discussions in this matter are to start in spring 2018 - an agreement on the exit of the United Kingdom from the EU is to be accompanied by a political declaration which will indicate the framework for future trade relations. For formal reasons, the negotiations and signing of an appropriate trade agreement between the United Kingdom and the EU will only be possible after the United Kingdom ceases to be a member of the EU. This means that it will be necessary to negotiate an additional agreement on the transitional period for the period after the UK's withdrawal from the EU and before the entry into force of the new trade agreement. In a joint report adopted at the beginning of December 2017 and closing the first stage of negotiations, the United Kingdom and the EU agreed that it would be crucial to negotiate terms for the transition period as soon as possible [Joint Report, 2017]. At the end of January 2018, ministers of the EU Member States decided that the transition period should not go beyond the current financial perspective, i.e. to the period after 31 December 2020.

As agreed in the Joint Report from the first phase of negotiations, the payment and disbursement of the UK from the EU budget will not change until 2020. The United Kingdom will most likely continue to participate in the EU programmes and policies and will maintain access to the single European market in return for respecting financial commitments until the end of the current financial perspective [Joint Report, 2017]. However, a significant problem may appear as early as 1 January 2021 . As indicated by experts, the planned 21 months of the transitional period (from 30 March 2019 to 31 December 2020) seem too short a time to negotiate and enter into force a new and comprehensive trade agreement between the United Kingdom and the EU [cf. Matthews, 2017]. The problem is not only the limitations resulting from the adopted negotiation schedule, but also (and above all) the diverse expectations, interests and preferences of the UK and the EU regarding the form of the future agreement. 
In the discussions, there are various proposals for arranging future relations between the EU and Great Britain, differing in the level of liberalization of mutual trade and the scope of co-operation. As part of the options allowing for the so-called soft Brexit, the Norwegian model is most often mentioned - integration and cooperation of Great Britain with the EU within the European Economic Area (EEA) - along with the Swiss model based on bilateral agreements providing a similar level of economic and trade integration between the parties. Agreements based on these models assume the creation of a free trade area and participation in the single European market. A country wishing to participate in the single market is required to adopt and apply the EU regulations in this area, together with relevant case law of the Court of Justice of the EU, and to make a specific financial contribution to the EU budget. However, it does not affect the prepared law and cannot participate in the work of the EU institutions. Other models referred to in the discussions assume the creation of a partial customs union between the United Kingdom and the EU, similar to the customs union between Turkey and the EU, or the creation of a deep and comprehensive free trade area, modelled on solutions adopted in the EU agreements with Ukraine or Canada. However, the British party underlines that none of the known models currently used in agreements linking the EU with third countries will be suitable for the United Kingdom [Treasury Committee, 2016]. The geographical proximity of Great Britain and the economic relations with the EU countries built for decades, resulting in close links at the level of sectors, industries and enterprises, make the United Kingdom a unique case. The EU-27 trade exchange with the United Kingdom is many times greater than the EU-27 trade exchange with Canada, Norway or Ukraine. The British economy is also a very important link in the EU's value chains ${ }^{18}$.

As implied from the statements and political declarations of the British authorities, Great Britain will strive to conclude a completely new agreement (bespoken agreement) between the EEA agreement (Norwegian model) and the CETA agreement (Canadian model) [Owen, Stojanovic and Rutter, 2017]. The EU negotiators also stress the importance and meaning of maintaining the closest possible economic and trade relations. At the same time, however, both sides point out to the existence of red lines which they cannot cross in the negotiations. These are the points that significantly limit the possible compromises (Table 1).

\footnotetext{
${ }^{18}$ For example, in 2011, the share of the added value generated by the British economy in exports of products of the EU-27 food industry amounted to $2.11 \%$ on average. The British economy made a particularly large contribution to the added value of exports of agriculture and food products in Ireland (11.6\% and 8.8\%, respectively). The contribution of the EU-27 economies to the added value of exports of these product groups for the United Kingdom was at the level of $10.5 \%$ and $12.6 \%$, respectively [Bellora and Foure, 2017].
} 
Table 1. Comparison of the UK and the EU negotiating goals in Brexit negotiations

\begin{tabular}{|c|c|c|}
\hline & Great Britain & European Union \\
\hline Objectives & $\begin{array}{l}\text { - secure the most frictionless pos- } \\
\text { sible trade in goods and services } \\
\text { outside the single market and } \\
\text { the customs union } \\
\text { - avoide the necessity to build any } \\
\text { physical infrastructure around } \\
\text { the Irish border }\end{array}$ & $\begin{array}{l}\text { - establish a close partnership with } \\
\text { the UK and a balanced, ambitious } \\
\text { and wide-ranging free trade area } \\
\text { avoide a hard border in the island of } \\
\text { Ireland }\end{array}$ \\
\hline Red lines & $\begin{array}{l}\text { - end the direct jurisdiction of the } \\
\text { Court of Justice of the EU in the } \\
\text { UK } \\
\text { - end of the free movement of } \\
\text { people } \\
\text { - end mandatory contributions to } \\
\text { the EU budget } \\
\text { - freedom to pursue an independ- } \\
\text { ent trade policy }\end{array}$ & $\begin{array}{l}\text { - } \text { preserve integrity of the single mar- } \\
\text { ket, including the indivisibility of } \\
\text { the four freedoms } \\
\text { ensure a level playing field, particu- } \\
\text { larly on competition and state aid, } \\
\text { and create safeguards against unfair } \\
\text { competitive advantages } \\
\text { - preserve the autonomy of the EU } \\
\text { legal order and its decision-making } \\
\text { - safeguard financial stability of the } \\
\text { EU, and respect its regulatory and } \\
\text { supervisory regime and standards } \\
\text { ensure the UK does not have a bet- } \\
\text { ter deal than EU Member States } \\
\text { avoid upsetting existing relations } \\
\text { with other third countries }\end{array}$ \\
\hline
\end{tabular}

Source: Owen, Stojanovic and Rutter 2017, p. 41.

The British vision of a completely new type of agreement excludes participation in the common market and the customs union. However, it assumes duty-free trade as part of the free trade area and additionally it eliminates non-tariff barriers and other obstacles that usually occur in such zones. As the EU party points out, these are the benefits of participating in the customs union and the common market, which are linked to specific obligations. Granting access to the internal market without taking any commitment or meeting the EU requirements would mean that the United Kingdom (without having the status of a member) would enjoy greater privileges and benefits than the EU Member States.

\subsection{The future of the EU finances and the CAP in the context of Brexit}

Negotiations on the UK's withdrawal from the EU and its future trade relations with the Union will take place in parallel with the intra-EU negotiations on the future of the CAP and the EU's Multiannual Financial Framework (MFF) for 2021-2027. Both processes can interact with each other to some extent. If the United Kingdom does not divorce fully the EU, and the political declaration attached to the UK's exit agreement with the EU will refer to the possible finan- 
cial commitments of the United Kingdom to the EU in the future, talks about the EU finances may be more favourable. However, it should be emphasized that the possible UK payments to the EU budget after 2020, being part of a possible agreement on the access of this country to the common market or to similar benefits, will not solve the problem of the permanent EU income gap that will occur as a result of Brexit. In the previous financial perspective 2007-2013, the contribution of the United Kingdom, after deducting the British rebate, accounted for $10.7 \%$ of the EU revenues on average per year. In recent years, this share has increased further. In the first three years of the current financial perspective (2014-2016), it amounted to $12.3 \%$ on average per year. None of the scenarios considered assumes that the possible payments negotiated under the agreement on future UK relations with the EU are close to the current membership contributions of that country. Currently, the United Kingdom ranks fourth in the EU in terms of the amount of contributions to the EU budget (after Germany, France and Italy). At the same time, it is the third largest net contributor to the EU budget (after Germany and France, before Italy, the Netherlands, Sweden and Austria) and the second largest net contributor to the CAP budget (after Germany, before Italy, the Netherlands, Belgium, France and Sweden). For this reason, the gap due to the lack of payment of Great Britain's contribution to the EU budget will be much greater than the reduction of expenses from the EU budget due to the United Kingdom's exit [Kawecka-Wyrzykowska, 2017].

The level of the gap in the EU income after Brexit is estimated in various ways. When counting based on the UK payments, not taking into account the UK rebate, after deducting transfers for the UK from the EU budget and based on the average for 2014-2015, it may amount to an average of EUR 16.6-17 billion per year [Kawecka-Wyrzykowska, 2017; Begg, 2017]. Calculations based on the methodology including the UK payments with a rebate and after deduction of transfers to the UK point out to a gap of around EUR 10 billion (both for the average for 2014-2015 and for 2014-2016) [Haas and Rubio, 2017]. There are also studies showing a smaller budget gap after Brexit, including the elaboration by Nuñez-Ferrer and Rinaldi [2016], who based on the data from 2014 and on the net payments of the United Kingdom on a reimbursement resulting from the rebate, indicated an amount of EUR 7.1 billion. Studies taking into account the British rebate in the calculations (reimbursement for the United Kingdom) assume that the amounts paid by other Member States to finance it, are already part of the national budget accounts and will not, therefore, mean new financial burdens for the EU-27 after the exit of Great Britain. Analysts also point to the fact that even in the case of hard Brexit, the revenue gap may be lower due to additional funds that will flow into the traditional EU own re- 
sources as a result of customs duties on goods originating from the UK. Nevertheless, taking into account even the most optimistic estimates, the loss of British payments will mean either the need to increase the contributions of other Member States in order to cover the gap after Brexit, or the need to significantly reduce the current expenditure.

It can be expected that the pressure to limit expenditure will be the highest for those EU policies that are currently allocated the largest amount of the EU budget funds. Cohesion Policy is such a policy next to the CAP, they both collectively account for over $80 \%$ of the EU spending. As Haas and Rubio [2017] note, if contributions of the EU-27 Member States are not increased, the scope of the required expenditure cuts will be so great that reductions in any other areas (such as migration or defense policy) will not be able to solve the problem. If the expenditure on these policies was reduced, these amounts would be relatively small, from the point of view of the measures needed to fill in the gap caused by Brexit, and on the other hand, huge for these policies themselves. In addition, the new challenges faced by the EU mean that the EU's new policies focused on migration, security and defense are more needed by the EU than ever before. Therefore, the pressure to increase rather than limit spending on these goals is likely to grow.

The framework for discussion on the future EU priorities and their financing was outlined by the European Commission by publishing two documents in 2017 - the White Paper on the future of Europe [European Commission, 2017a] and the Book on Reflection on the future of EU finances [European Commission, 2017b]. Separate communication, published at the end of November 2017, was devoted to the future of agriculture and food production in Europe [European Commission, 2017c]. Although the Brexit budget effects are not analysed in the documents indicated, the proposals contained in them take into account the probable gap in the EU income related to the UK's exit. In the White Paper on the Future of Europe, the Commission presented five scenarios of the EU development outlining various reform proposals and their implications for the EU budget. The Commission has addressed these scenarios in more detail in the next document - the Reflection Paper prepared in June 2017 by the Directorate-General for Budget and devoted entirely to the future of EU finances. Four out of five scenarios set forth a reduction of the EU budget, including the CAP budget. Only the fifth scenario mentions significantly larger funds. However, in the case of the CAP, the Commission does not indicate any priorities in this scenario, which leads to the assumption that it is not seriously considered.

In the Reflection Paper, the Commission also mentions the possibility of introducing co-financing of direct payments so as to maintain the overall levels of current support under the CAP. This proposal is synonymous with accepting 
a reduction in the CAP expenditure financed from the common budget. In a press release, Commissioner for Regional Policy, Corina Creţu pointed out that currently only agriculture is $100 \%$ financed from the EU budget. At the same time, she stressed that, given the likely limitations of the EU budget in the future, national co-financing could be a solution for direct payments ${ }^{19}$. This proposal was criticized by the Commissioner for Agriculture, Phil Hogan. The option of co-financing direct payments was rejected as inappropriate in the first and working version of the communication on agriculture and the CAP. However, the final version of the document emphasizes that the Communication does not prejudge the outcome of the debate on the EU budget and multiannual financial framework [European Commission, 2017c, p. 9]. This means that the option of co-financing direct payments will be subject to further analysis by the Commission services and may appear in the legislative proposals for the future financial framework and the CAP.

Matthews [2017] emphasizes that the CAP budget will most likely be reduced not only in relative terms but also in absolute numbers in the next MFF. On the other hand, the reduction of budgetary resources will affect the shape of the EU agricultural policy. In autumn 2017, the commissioner for EU budget Günter Oettinger pointed to the need to investigate the impact of possible cuts in the overall EU budget at the level from 15 to $30 \%{ }^{20}$. At the same time, the Commissioner for Regional Policy mentioned above, suggested the possibility of adoption of a $5 \%$ co-financing rate for direct payments. It can be expected that a group of supporters of reducing the common budget for the CAP will grow among the Member States. The support for accepting co-financing of direct payments will also probably increase. As pointed out by Kaiser and PrangeGstöhl [2017], the distribution between net contributors and net beneficiaries of the budget, based on the logic of fair return, will continue to play a dominant role in the MFF negotiations. However, it is difficult to predict the outcome of talks on the future EU financial framework and the budget for the CAP. On the one hand, the consent of Member States to increase national contributions to the EU budget is unlikely. On the other, Brexit may increase the pressure to conclude an agreement to overcome the crisis and strengthen the future EU.

\footnotetext{
${ }^{19}$ Radosavljevic Z., Commission mulls CAP cuts, rebates in effort to shore up post-2020 budget, Euractive, https://www.euractiv.com/section/uk-europe/news/commission-mulls-cap-cuts-rebates-in-effort-to-shore-uppost-2020-budget/, 28.06.2017.

${ }^{20}$ Eder F., Commission gets glimpse of post-Brexit EU budget horrors, Politico, https://www.politico.eu/article/commission-gets-glimpse-of-post-Brexit-eu-budget-horrors/ 22.11.2017.
} 


\subsection{Impact of possible changes in the CAP budget on the net balance of Poland and transfers to the Polish agriculture}

Poland is currently the largest net beneficiary of the CAP in the EU. In the first two years of the EU membership (2004-2006), the net balance of Poland in the CAP area (financial transfers for Polish agriculture after deduction of contributions paid by Poland to the CAP budget ${ }^{21}$ ) amounted to EUR 328 million on average per year. This amount in the first two years of the current financial perspective (2014-2016) increased to EUR 3125 million on average per year. Without taking into account the financial settlements between the national budget and the CAP budget, the Polish agricultural sector received support of almost EUR 5 billion on average per year in this period. At the same time, the load on net contributors in the CAP budget increased significantly. Particularly strong growth was in the United Kingdom - the negative net balance of the United Kingdom in the CAP increased to approx. EUR 3 billion on average per year (from approx. EUR 1 billion on the basis of data from the first two years of the previous financial perspective). For the CAP budget, Brexit will therefore mean a loss of approx. EUR 3 billion on average per year. However, taking into account the total gap in the EU's revenue after Brexit, the pressure to limit the CAP budget may go beyond the amount resulting from the net balance of the United Kingdom in this area.

An attempt to take a closer look at the possible consequences of Brexit for the EU budget and the CAP budget was made by Haas and Rubio [2017] at the request of the European Parliament. The impact of Brexit was measured by these authors by changes in the net budgetary balances of Member States defined as payments made by Member States calculated on the basis of VAT receipts and based on GNP, less total EU expenditure in that state. The methodology used by Haas and Rubio to assess the impact of Brexit on the CAP budget required, in the first step, implementation of a simplified British rebate based on the CAP expenditure, so that adding the initial contribution of the Member State to the CAP budget, the effect of end of rebates and the costs of covering the missing UK net contribution gave a state's payment to the CAP budget ${ }^{22}$. The study by Haas and Rubio [2017] analyses five scenarios:

- Scenario 1, assuming an increase in payments of the Member States to the CAP budget by EUR 3 billion to cover the gap resulting from the missing payments from the United Kingdom;

\footnotetext{
${ }^{21}$ Although there are no official statistics concerning the Member States' contributions to individual policies in the EU budget statements, they can be estimated by comparing the state's share of the EU budget with the state's share of the EU spending in the given area.

${ }^{22}$ Details of the methodology used are explained by Haas and Rubio on pages 27 and 28 of their study [Haas and Rubio, 2017].
} 
- Scenario 2, assuming a reduction in the CAP budget by the missing amount of EUR 3 billion;

- $\quad$ Scenario 3, assuming a reduction in the CAP budget for both pillars by EUR 10 billion (i.e. by the amount corresponding to the total estimated budget gap after Brexit);

- $\quad$ Scenario 4, assuming a reduction in the CAP budget for $1^{\text {st }}$ pillar in the EU-27 (direct payments) by EUR 10 billion;

- Scenario 5, assuming a reduction in the CAP budget for $1^{\text {st }}$ pillar in the EU-27 (direct payments by 10 billion in the EU-14 (in the so-called old EU Member States).

The scenarios for adjusting the CAP budget to the upbeat reality proposed by Hass and Rubio will be the reference point in assessing the possible impact of Brexit on the net balances of Poland and transfers to Polish agriculture. However, the fifth scenario will be modified in the assessment presented below because the reductions provided for in it refer only to the old Member States. A scenario will be considered instead, assuming that direct payments paid to farmers after reallocation of funds between the pillars (in the case of Poland after reallocation $25 \%$ from $2^{\text {nd }}$ to $1^{\text {st }}$ pillar) will be taken into account for the possible reduction in $1^{\text {st }}$ pillar at the level of EUR 10 billion. At the same time, due to the goal set in the introduction, a sectoral approach will be added - a summary of changes in financial transfers that would ultimately reach the Polish agricultural sector after the implementation of individual scenarios. The assessment of the effects of budget changes for Poland will be accompanied by a reference to changes in net balances of other Member States, so as to bring closer the interests and positions that may appear in the negotiations on the future EU financial framework and the CAP budget.

According to the estimates, in all the analyzed scenarios there would be a deterioration of Poland's net balances in the CAP area. With the exception of the first scenario (increase in membership fees by EUR 3 billion), there would also be a decrease in payments from the CAP budget to Polish agriculture (Figure 1). 
Figure 1. Estimated Brexit effects for net balances of Poland and transfers in the CAP area (scenario 1-4 by Haas and Rubio and scenario 5 after reallocation of funds between the pillars)

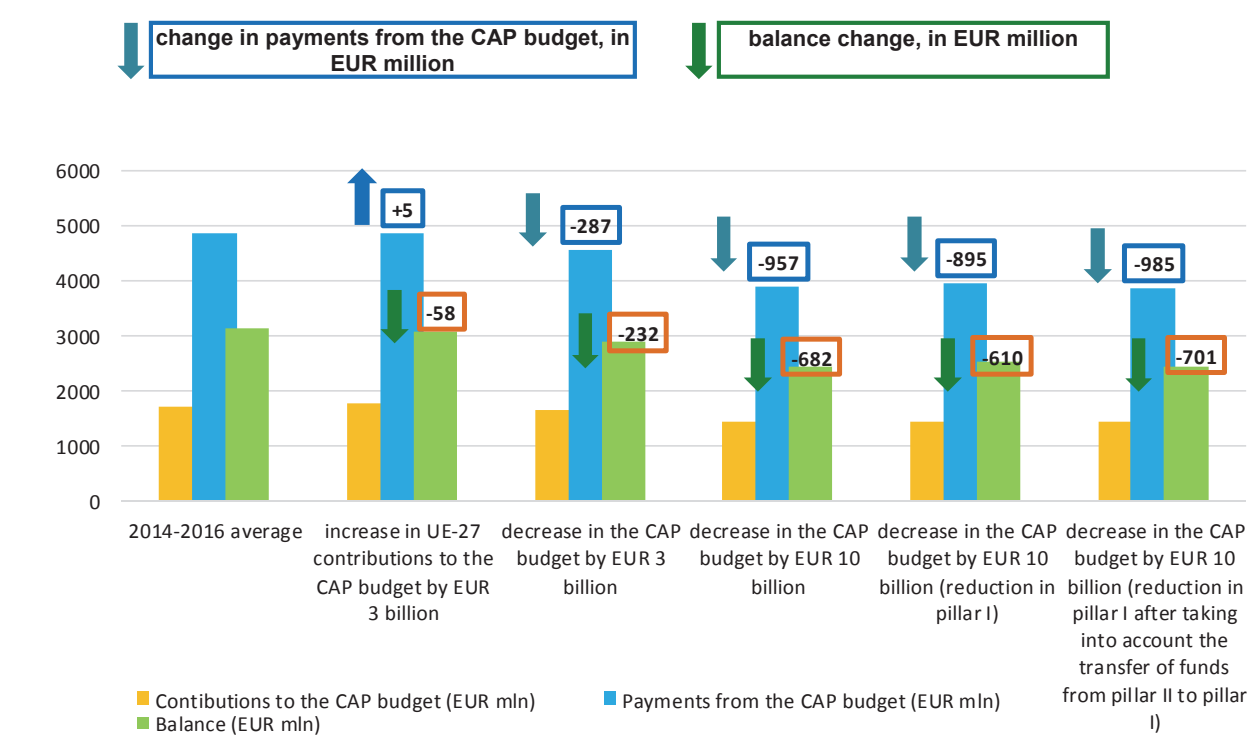

Source: own calculations based on data from the European Commission, http://ec.europa.eu/budget/figures/interactive/index_en.cfm based on the Haas and Rubio methodology [2017].

Average payments and disbursements from the CAP budget for the period of 2014-2016 (for Poland they amounted to EUR 1717 million and EUR 4842 million, respectively) are the reference point in the assessment of changes in payments and disbursements from the CAP budget under the analysed scenarios. In the first scenario of supplementing the CAP budget gap with additional contributions from the Member States in the amount of EUR 3 billion, Poland would have to pay a bit more to the CAP budget (about EUR 60 million more than currently), but at the same time transfers to the sector would be higher by approx. EUR 5 million. The increase in payments would result in deterioration of the Polish balance by EUR 58 million. The deterioration of net balances in the area of the CAP would also be noted by other Member States. However, the largest burden would be borne by net contributors who used rebates for the British rebate (Germany, Austria, the Netherlands and Sweden) [Haas and Rubio, 2017]. It can be expected that these countries will protest most against the scenario of increasing payments to the CAP. 
In the scenario with reductions of the CAP budget at the level of EUR 3 billion, both payments to and from the CAP budget would be lower than at present. Payments would decrease by EUR 287 million, and the net balance would get worse by approx. EUR 232 million. The net balance of the other main beneficiaries of the CAP (Spain, Greece and Romania) would also deteriorate. However, the planned cuts would be insufficient to maintain the current load of the main net contributors to the CAP budget. Implementation of this scenario would still result in a significant deterioration of their net balances. There will most probably be a strong pressure by the main contributors for deeper reductions, not so much as to reduce their payments, which will keep the current state of burdens.

In the scenario of radical reductions at the level of EUR 10 billion for both pillars, Poland would have to pay a little less to the CAP budget than in the previous scenario, but would receive much less funds. Transfers to Polish agriculture would decrease by over EUR 950 million, and the balance would worsen by approx. EUR 680 million. In this scenario, the cost of financing Brexit would fall on all major beneficiaries of the CAP - apart from Poland, it would be Spain, Greece, Romania and Bulgaria. If the budget of the CAP was reduced by EUR 10 billion, Germany could maintain a negative balance (currently - EUR 5 billion) at an unchanged level. Other net contributors to the CAP budget, however, would see an improvement in their balances, although there would still be negative balances. The adoption of this scenario, however, seems unlikely as it would undermine the principle of solidarity in force in the EU.

In the fourth scenario, assuming reductions at the level of EUR 10 billion only in $1^{\text {st }}$ pillar (for direct payments), the unfavourable balance for Poland slightly decreases compared to the third scenario, but it would still be a huge drop. Transfers to Polish agriculture would be lower by approx. EUR 895 million, and the net balance would be worse by EUR 610 million. In this scenario, Poland and other new Member States are less affected by cuts than in the previous scenario due to the relatively higher importance of $2^{\text {nd }}$ pillar in the support structure. It is worth emphasizing, however, that the estimates under this scenario do not take into account the possible reallocation between the pillars.

The largest declines in transfers and the balance of Poland would occur if direct payments are covered by reductions after reallocation of funds from $2^{\text {nd }}$ pillar to $1^{\text {st }}$ pillar (fifth scenario). Taking into account the financial flows only, this scenario would be more unfavourable for Poland than the scenario providing for reductions in both pillars. Under this scenario, Poland would contribute EUR 1432 million to the budget of the CAP (by approx. EUR 300 million less than at present) and would receive EUR 3856 million (by almost EUR 1 billion less than at present). Haas and Rubio [2017] indicate that the introduction of co- 
-financing direct payments (after a reduction of EUR 10 billion) could change the budgetary impact of the cuts, especially if differentiated co-financing rates are foreseen, depending on the level of affluence of individual Member States. However, co-financing of direct payments is an option that will be difficult to accept for Poland and the other new EU Member States. The reason is not only the lower level of affluence of the new Member States, but also the existing disproportions in the distribution of direct payments between Member States resulting from the distribution criteria used in the past. In the Communication of November 2017, the Commission envisages further external convergence for direct payments. It is possible, however, that the level of payments being the reference point for eliminating disparities in the distribution of funds will be lower than at present. This may mean that despite the planned convergence, Poland may receive a smaller envelope of funds in the next financial perspective, or in a more optimistic scenario, not assuming a reduction in the CAP budget - to maintain the current envelope.

The reduction of the CAP expenditure, including the reduction of the budget for direct payments, may negatively affect the competitiveness of the Polish food sector. This is due to the relatively high share of direct payments in the incomes of individual farms in Poland. There are types of farms where direct payments account for more than half of the income. A particularly high level of dependence on external support concerns dairy farms and slaughter cattle farms - depending on the type and size of the farm, the share of direct payments in income ranges from 30\% to 95\% [Ziętara and Adamski, 2017]. Lowering the level of payments could not only have a negative impact on the economic situation of farms in Poland, but also threaten the stability of the raw material base for the food industry. Food production in Poland is still primarily based on raw materials from domestic agriculture [Szczepaniak, 2017]. The indicated solution in the form of supplementing the support level from the CAP budget with support from national budgets (co-financing of direct payments) could not provide the expected results. The co-financing rate referred to in the discussions at the level of $5 \%$ would imply a burden on the Polish budget of around PLN 680 million on average per year. However, it is not known whether additional support from the domestic budget would be possible. Concerns can also be raised as to whether introduction of co-financing of direct payments will lead to the strengthening of flexibility principle in the management of agricultural support in the EU and, as a result, to diversification of the conditions of competition in the common market. 


\subsection{The potential impact of Brexit on agri-food trade between Poland and the United Kingdom}

Despite the ongoing negotiations between the European Union and the United Kingdom, it cannot be clearly excluded that an agreement between the parties will not be reached. Lack of agreement would mean that trade should be conducted on the general principles adopted in the WTO, i.e. reintroduction of customs duties under the Most Favoured Nation Clause (MFN). Assuming that the United Kingdom would adopt the EU customs tariff, in majority of the most important product groups in the Polish exports to the United Kingdom (according to the four-digit HS classification), relatively high (over 20\%) MFN duty rates would apply ${ }^{23}$.

Table 2. The most important product groups in Poland's agri-food exports to Great Britain in 2016

\begin{tabular}{|c|l|c|c|c|}
\hline $\begin{array}{c}\text { Code } \\
\text { HS }\end{array}$ & \multicolumn{1}{|c|}{ Code description } & $\begin{array}{r}\text { Value } \\
\text { in EUR } \\
\text { million }\end{array}$ & $\begin{array}{c}\text { Share } \\
\text { in \% }\end{array}$ & $\begin{array}{c}\text { MFN customs duty on } \\
\text { imports into the EU } \\
\text { in \%* }\end{array}$ \\
\hline 1806 & Chocolate and chocolate products & 282.7 & 13.0 & $40 \%$ \\
\hline 0207 & Poultry meat and offal & 234.4 & 10.8 & $20-35 \%$ \\
\hline 1905 & $\begin{array}{l}\text { Confectionery, cakes and pastries, biscuits } \\
\text { and other bakery products }\end{array}$ & 155.3 & 7.2 & $40-45 \%$ \\
\hline 1602 & Other meat and offal, processed or preserved & 139.8 & 6.5 & $35-115 \%$ \\
\hline 2402 & Cigarettes & 111.4 & 5.1 & $57.6 \%$ \\
\hline 1601 & $\begin{array}{l}\text { Sausages and similar products of meat and } \\
\text { offal }\end{array}$ & 100.9 & 4.7 & $32-40 \%$ \\
\hline 0210 & $\begin{array}{l}\text { Meat and offal, salted, in brine, dried or } \\
\text { smoked }\end{array}$ & 93.3 & 4.3 & $18-56 \%$ \\
\hline 0709 & $\begin{array}{l}\text { Other vegetables, fresh or chilled (including } \\
\text { champignon mushrooms) }\end{array}$ & 71.0 & 3.3 & $12.8 \%$ \\
\hline 0201 & Beef meat, fresh or chilled & 63.6 & 2.9 & $65 \%$ \\
\hline 1604 & Processed or preserved fish & 54.4 & 2.5 & $5.5-20 \%$ \\
\hline \multicolumn{2}{|l|}{ Top 10 product groups in export } & 1306.8 & 60.3 & $\times$ \\
\hline
\end{tabular}

* The rate of customs duty on imports into the EU of the most important products within a given group according to HS4. Italics indicate the estimated ad valorem equivalents of specific rates.

Source: unpublished data of the Ministry of Finance and TARIC.

\footnotetext{
${ }^{23}$ The duty rates for importing the most important products to the EU within a given group distinguished by a four-digit HS code are given.
} 
The highest level of protection would concern Polish exports, among other meat (poultry and beef) as well as meat and offal products (e.g. sausages), cigarettes, chocolate and chocolate products as well as confectionery and pastry goods. It can be expected that the introduction of customs tariffs in the export to the United Kingdom will increase the prices of Polish products on the British market, deteriorate their price competitiveness and, as a result, decrease the exports. This effect may additionally be strengthened as a result of the increased level of non-tariff barriers (including sanitary and phytosanitary measures, technical barriers, certification procedures). According to estimates by Bellora et al. [2017], the equivalent of non-tariff barriers in the EU exports of dairy products to the United Kingdom may increase in the absence of agreement from $42 \%$ to $74 \%$, processed meat - from $24 \%$ to $43 \%$, fruit and vegetables - from $18 \%$ to $32 \%$, fats and oils - from $22 \%$ to $38 \%$, beverages and cigarettes - from $14 \%$ to $25 \%$.

In the event of disagreement between the EU and the UK, the MFN duty rates in the Polish imports of the most important product groups from the United Kingdom would be lower than in the Polish exports to the British market (Table 3). In imports of five of the ten product groups analysed here, the duty rates would not exceed $15 \%$. This would apply to fresh or chilled fish, fish fillets, sauces and preparations for them as well as pet food. Import of whiskey, which is the most important product in import, would still be duty-free. The highest duty (over 50\%) would apply to imports of processed tobacco, poultry meat and offal. Increasing the protection would cause an increase in prices of British products on the Polish market and, consequently, a fall in demand and a reduction in imports. Similarly, as in the case of Polish exports to the United Kingdom, non-tariff barriers would also significantly increase imports to Poland from the UK. As implied from the estimates of Bellora et al. [2017], the equivalent of non-tariff barriers in some commodity groups may be even higher than in exports to the United Kingdom. Imports to the EU of dairy products would (in the absence of an agreement between the EU and the United Kingdom) amount to almost 84\%, processed meat and offal $-58 \%$, and vegetable fats and oils $-49 \%$.

Based on the estimates of the authors mentioned above [Bellora et al., 2017] it appeared that, in the absence of agreement, the average MFN duty rate in Poland's exports to Great Britain (weighted by the structure of Polish exports to this country) would amount to $21.3 \%$, and the non-tariff barriers equivalent would increase from $28 \%$ to $49 \%$. In turn, the average weighted MFN duty rate for imports to Poland from the United Kingdom would be $14.2 \%$, and the equivalent of non-tariff barriers would increase from $17 \%$ to $30 \%$. 
Table 3. The most important product groups in Poland's agri-food imports to Great Britain in 2016

\begin{tabular}{|c|l|c|c|c|}
\hline $\begin{array}{c}\text { Code } \\
\text { HS }\end{array}$ & \multicolumn{1}{|c|}{ Code description } & $\begin{array}{c}\text { Value } \\
\text { in EUR mil- } \\
\text { lion }\end{array}$ & $\begin{array}{c}\text { Share } \\
\text { in } \%\end{array}$ & $\begin{array}{c}\text { MFN customs duty } \\
\text { on imports into the } \\
\text { EU, } \%\end{array}$ \\
\hline 2208 & Whisky & 95.1 & 18.2 & $0 \%$ \\
\hline 0203 & Pork meat & 75.2 & 14.4 & $28 \%$ \\
\hline 2106 & $\begin{array}{l}\text { Other food preparations (e.g. powders for produc- } \\
\text { tion of creams, jellies, beverages) }\end{array}$ & 42.1 & 8.1 & $25 \%$ \\
\hline 1806 & Chocolate and chocolate products & 39.0 & 7.5 & $36 \%$ \\
\hline 0302 & Fresh or chilled fish & 29.4 & 5.6 & $2 \%$ \\
\hline 2403 & Other processed tobacco, tobacco extracts & 23.5 & 4.5 & $17-75 \%$ \\
\hline 2103 & $\begin{array}{l}\text { Sauces and preparations for them, and mixtures of } \\
\text { spices }\end{array}$ & 17.6 & 3.4 & $7.7 \%$ \\
\hline 2309 & Pet food & 15.6 & 3.0 & $0-9.6 \%$ \\
\hline 0207 & Poultry meat and offal & 12.0 & 2.3 & $5.4 \%$ \\
\hline 0304 & $\begin{array}{l}\text { Fish fillets and other fish meat, fresh, chilled or } \\
\text { frozen }\end{array}$ & 9.4 & 1.8 & $7.5-15 \%$ \\
\hline \multicolumn{1}{|c|}{ Top 10 product groups in import } & 358.9 & 68.7 & $\times$ \\
\hline
\end{tabular}

* The rate of customs duty on imports into the EU of the most important products within a given group according to HS4. Italics indicate the estimated ad valorem equivalents of specific rates.

Source: unpublished data of the Ministry of Finance and TARIC.

\subsection{Summary and conclusions}

The UK's exit form the EU will result in many economic, social and political changes, both in the EU and in the UK itself. From the point of view of the development prospects of the Polish food sector, the gap in the EU revenues resulting in a possible reduction of the CAP budget will be one of the most important effects of Brexit. Reductions in this area may mean a lower level of support for Polish agricultural producers in the next EU 2021-2027 financial perspective. However, the outcome of the negotiations on the next multiannual financial framework is difficult to predict at this point. This will depend, e.g. on a new balance of power between net payers and beneficiaries of the EU budget, political compromises on the EU's financial priorities, as well as the provisions of the agreement on future relations between the UK and the EU.

The moderately optimistic scenarios for the future CAP budget assume reductions at the level corresponding to the United Kingdom's net contribution to the CAP budget (EUR 3 billion). Radical scenarios indicate cuts corresponding to the total UK contribution to the EU budget (EUR 10 billion). If we adopt these two scenarios, the range of possible reduction of transfers to the Polish agricultural sector would range from almost EUR 290 million to over EUR 980 
million on average per year. The current course of the debate on the future of the CAP indicates that reductions may cover mainly direct payments. In the documents published in 2017, the European Commission considered lowering the CAP budget and also signalled the possibility of introducing co-financing of direct payments. If the reduction scenario is implemented, it is likely that the competitiveness of the Polish agricultural sector will deteriorate due to the currently relatively high share of direct payments in the income of the Polish farmers.

Brexit can mean unfavourable changes not only for farmers but also for all entities involved in agri-food trade. The scenario of introducing duties on agri-food products in mutual trade between Poland and the United Kingdom (hard Brexit) will most likely lead to the effect of shifting trade to cheaper suppliers in both countries. Therefore, one can expect a breakdown in the Polish exports to Great Britain of the most important groups of agri-food products, and the most of processed meat, cigarettes and beef (possible increase of prices on the British market by over $50 \%$ ), chocolate and chocolate products as well as confectionery and pastry products. The increase in the level of non-tariff barriers will be an additional difficulty in access to the British market for the Polish agri-food products. Imports to Poland can be expected to encounter a clearly smaller decrease than exports to the British market. Among the most important import items, imports of poultry, processed tobacco, chocolate and chocolate products as well as pork meat can decrease the most.

\section{References}

1. Begg, I. (2017). The EU budget after 2020, European Policy Analysis 9/2017, SIEPS.

2. Bellora, C., Fouré, J. (2017). EU - UK agricultural trade: State of play and possible impacts of Brexit, Presentation for the Committee on Agriculture and Rural Development of the European Parliament, 9.11.

3. Bellora, C., Emlinger, C., Fouré, J., Guimbard, H. (2017). Research for AGRI Committee, EU - UK agricultural trade: state of play and possible impacts of Brexit, European Parliament, Policy Department for Structural and Cohesion Policies, Brussels.

4. EU expenditure and revenue 2014-2020. Retrieved from: http://ec.europa.eu/ budget/figures/interactive/index_en.cfm.

5. European Commission (2017a). White Paper on the future of Europe, COM (2017) 2025.

6. European Commission (2017b). Opening document for the debate on the future of EU finances, COM (2017) 358.

7. European Commission $(2017 \mathrm{c})$. The future of agriculture and food production, Communication from the Commission to the European Parliament, the Council, 
the European Economic and Social Committee and the Committee of the Regions, $\operatorname{COM}(2017) 713$ final.

8. Haas, J., Rubio, E. (2017). Research for AGRI Committee - Possible impact of Brexit on the EU budget and, in particular, CAP funding, European Parliament, Policy Department for Structural and Cohesion Policies, Brussels.

9. Joint report from the negotiators of the European Union and the United Kingdom Government on progress during phase 1 of negotiations under Article 50 TEU on the United Kingdom' orderly withdrawal from the European Union, 8 December 2017 TF50 (2017) 19 - Commission to EU 27.

10.Kaiser, R., Prange-Gstöhl, H. (2017). The Future of the EU Budget Perspectives for the Funding of Growth-Oriented Policies post-2020, report no. 6, SIEPS, September.

11. Kawecka-Wyrzykowska, E. (2017). Implikacje Brexitu dla finansowania UE, ze szczególnym uwzględnieniem skutków dla Polski, seminar, SGH Warsaw School of Economics, 6.10.2017.

12.Kierzenkowski, R., Pain, N., Rusticelli, E., Zwart, S. (2016). The economic consequences of Brexit, OECD Economic Policy Paper, No 16., April.

13. Matthews, A. (2017). The budgetary context for the CAP after 2020, Blog CAP Reform.eu, September 4.

14.Núñez Ferrer, J., Rinaldi, D. (2016). The Impact of Brexit on the EU Budget: A non-catastrophic event. CEPS Policy Brief No. 347, September.

15. OECD (2017). United Kingdom - Overview. OECD Economic Surveys, October.

16. Owen J, Stojanovic, A., Rutter, J. (2017). Trade after Brexit. Options for the UK's relationship with the EU, Institute for Government, December.

17. Szczepaniak, I. (2017). Krajowe i importowane surowce w produkcji żywności w Polsce, "Przemysł Spożywczy" No. 4, pp. 2-5.

18.TARIC, Integrated Tariff of the European Union.

19. Treasury Committee of the UK Parliament, The economic and financial costs and benefits of the UK's EU membership, 2016. Retrieved from: https://publications parliament.uk/pa/cm201617/cmselect/cmtreasy/122/12202.htm.

20. Unpublished data of the Ministry of Finance.

21.Ziętara, W., Adamski, M. (2017). Konkurencyjność polskich gospodarstw mlecznych i z chowem bydła rzeźnego na tle analogicznych gospodarstw $\mathrm{z}$ wybranych krajów, Presentation at the IAFE-NRI seminar, Warsaw. 